\title{
UTILIZAÇÃO DAS CATEGORIAS LITERÁRIAS DE LUKÁCS NA PRÁXIS DO PROFESSOR DE LITERATURA
}

\author{
KARLA RAPHAELLA COSTA PEREIRA ${ }^{1}$; FREDERICO JORGE FERREIRA COSTA ${ }^{2}$ \\ ${ }^{1}$ Mestra em Educação pela UECE. CV: http://lattes.cnpq.br/6592056073051492 \\ ${ }^{2}$ Professor e Doutor em Educação pela UECE. CV: http://lattes.cnpq.br/7944751664196175
}

Artigo submetido em Junho/2016 e aceito em Julho/2016

\section{RESUMO}

Este artigo apresenta resultados de pesquisa de mestrado em Educação na área de formação de professores. Objetiva relacionar algumas categorias elencadas por György Lukács em artigos de crítica e teoria literária com a práxis do professor de literatura na escola pública brasileira. As categorias estudadas foram figuração, narração [centralidade da ação], fisionomia intelectual, autonomia, perspectiva, tipicidade e genericidade. A metodologia desenvolvida se compôs de duas partes fundamentais: pesquisa bibliográfica da obra de Lukács para elencar as características e categorias que esboçassem uma compreensão revolucionária da arte; em seguida, realizou-se um estudo documental das Orientações Curriculares Nacionais da área de Linguagens, códigos e suas tecnologias do capítulo sobre a literatura, centrando-se na captação dos fundamentos filosóficos e estéticos para a prática do professor de literatura. O estudo permitiu compreender que as diretrizes para o ensino de literatura tomam uma concepção de arte e de trabalho que se alinham aos interesses da sociedade capitalista. A pesquisa bibliográfica indicou que é possível construir elementos didáticos úteis ao ensino de arte e literatura para auxiliar na autoconsciência de si que a arte procura estabelecer no mundo dos homens.

PALAVRAS-CHAVE: Arte. Formação Docente. Formação Humana. Literatura.

\begin{abstract}
This article presents master's research results in education in teacher training area. It aims to relate some categories listed by György Lukács in critical articles and literary theory and literature teacher practice in the Brazilian public school. The categories studied were figuration, narration [centrality of action], intellectual face, autonomy, perspective, typicality and genericity. The methodology developed is composed of two fundamental parts: literature review of Lukacs's work to list the characteristics and categories esboçassem a revolutionary understanding of art; then carried
\end{abstract}

out a desk study of the National Curriculum Guidelines chapter on literature, focusing on capturing the philosophical and aesthetic grounds for the practice of literature professor. The study allowed us to understand that the guidelines for the teaching of literature take a conception of art and work that align the interests of capitalist society. The literature indicated that it is possible to build didactic elements useful to the teaching of art and literature to assist in self-awareness itself that art seeks to establish in the world of men.

Keywords: Art. Teacher Training. Human formation. Literature. 


\section{INTRODUÇÃO}

Este artigo apresenta resultados obtidos em pesquisa de mestrado em Educação com concentração na área de formação de professores. Alguns autores, a exemplo de Eric Hobsbawm, Mário Vargas Llosa e, antes deles, os próprios Marx e Engels, destacam a necessidade de discutir sobre o papel da arte e da literatura na sociedade capitalista. Nesta sociabilidade, a literatura tornou-se uma mercadoria e um produto de entretenimento de massa, tendo em vista os corriqueiros lançamentos de obras deste tipo e o crescimento do mercado editorial. É urgente pensar o papel do professor de literatura nesse contexto. A teorização sobre a realidade deve ter início na vida cotidiana e a ela retornar num movimento de enriquecimento. Da mesma forma, pesquisas sobre a práxis docente devem contribuir com o cotidiano escolar.

O estudo teve como objetivo relacionar algumas categorias elencadas por György Lukács em seus escritos de crítica e teoria literária com a práxis do professor de literatura na escola pública brasileira. A metodologia desenvolvida se compôs de duas partes fundamentais. Primeiramente, uma pesquisa bibliográfica da obra do filósofo húngaro György Lukács que trata da questão da arte e da literatura, citadas no próximo parágrafo, para elencar as características e categorias que esboçassem uma compreensão revolucionária desses dois objetos humanos. Em seguida, realizou-se um estudo documental das Orientações Curriculares Nacionais da área de Linguagens, códigos e suas tecnologias, especificamente do capítulo sobre a literatura. A escolha deste documento se justifica porque, dentre os que direcionam o ensino de linguagens, ele é o único que apresenta um capítulo específico para a literatura. A análise do documento centrou-se na captação dos fundamentos filosóficos e estéticos para a prática do professor de literatura na compreensão do discurso oficial exposto no documento.

A pesquisa bibliográfica centrou-se em seus artigos de teoria e crítica literária compilados em obras como Ensaios sobre literatura (1965), Arte e sociedade: escritos estéticos de 1932-1967 (2009), Marxismo e teoria da literatura (2010), Problemas del Realismo (1966), Materiales sobre el realismo (1977) e Escritos de Moscú: estúdios sobre política y literatura (2011). Os três primeiros compêndios são publicações em língua portuguesa e os dois últimos em língua castelhana que possuem em comum reunir obras de Lukács sobre arte e literatura. Não é possível citar todos os artigos estudados, por isso a opção de citar as obras onde podem ser encontrados.

Centrar o estudo na teoria lukacsiana se justifica pelo fato de o autor entender a arte como uma necessidade que nasce do cotidiano, ou seja, não como uma manifestação transcendente. A concepção materialista-dialética de Marx coloca no centro do debate a radical historicidade de todas as categorias estéticas como nenhum pensador anterior pôde solucionar. Marx finca estacas na assertiva de que a arte é um produto humano e só porque humano o homem faz arte.

As categorias elencadas foram figuração, narração [centralidade da ação], fisionomia intelectual, autonomia, perspectiva, tipicidade e genericidade. O método marxiano permitiu partir da prática do professor de literatura na sociedade capitalista, pela percepção de que ele se situa numa compreensão de arte que não leva em conta a percepção ontológica desse complexo social, sendo explicado apenas como epifenômeno na 
sociedade humana ou como uma capacidade inata e transcendente. Tal conclusão pôde ser tomada ao analisar as Orientações Curriculares Nacionais de Literatura que colocam a arte literária neste patamar, afastando-a da realidade cotidiana.

O movimento metodológico permitiu compreender que as diretrizes para o ensino de literatura tomam uma concepção de arte e de trabalho que se alinham aos interesses da sociedade capitalista. Tal demonstração aponta para a necessidade de organização da classe trabalhadora no sentido de conquistar uma escola pública e um ensino de arte e literatura que condigam com os interesses dos trabalhadores. A pesquisa bibliográfica com foco em expor as categorias acima mencionadas dá indicações de que é possível construir elementos didáticos úteis ao ensino de arte e literatura com foco em auxiliar na autoconsciência de si que a arte procura estabelecer no mundo dos homens. É possível afirmar que as teorizações lukacsianas podem contribuir com uma práxis docente revolucionária, daí a necessidade de que os professores tenham acesso a esse conhecimento.

\section{PARA QUE LITERATURA E ALGUMAS CATEGORIAS LITERÁRIAS LUCKASIANAS}

A literatura é uma forma particular de reflexo da realidade objetiva que existe independentemente da consciência humana; objetiva captar a realidade como ela realmente é, superando os limites do aparente. A meta do reflexo artístico é proporcionar uma imagem da realidade objetiva na qual haja uma evidente imediatez unitária, ou seja, na qual essência e fenômeno coincidam numa unidade espontânea (LUKÁCS, 1966, p. 20).

Estando o homem voltado para sua vida cotidiana e se relacionando com ela de forma imediata, a heterogeneidade e complexidade da realidade não são percebidas. A obra de arte, ao proporcionar que o homem se volte inteiramente para o mundo próprio nela figurado, permite um olhar mais aprofundado acerca de uma porção da totalidade intensificada em seu reflexo. A obra de arte deve proporcionar um salto qualitativo no receptor.

Entende-se aqui o caráter educativo da arte não no sentido de arte educativa, ou seja, obras que possuem um objetivo didático demarcado.. Lukács advertiu, algumas vezes, usando as palavras de Croce, que "a arte educa enquanto arte não enquanto arte educativa", ou seja, o que possibilita a arte educar o homem é, justamente, o que a faz arte. Lukács expôs algumas categorias que permitem a arte educar o homem e exercer sua função ontológica de reafirmar a humanidade construída historicamente. Alguns apontamentos didáticos acerca da possibilidade de uso da concepção realista da literatura de Lukács serão apresentados ao final deste texto.

A obra literária deve figurar uma totalidade, ou seja, os homens em suas ações, bem como os objetos e as instituições que medeiam suas relações entre si na sociedade e na natureza. A escolha daquilo que deve ser figurado não pode ser arbitrária, pois nasce da necessidade do próprio enredo, da representação dos destinos humanos. A figuração da totalidade do real é, portanto, essencial para a criação do mundo homogênio da obra literária.

Para Lukács (2010, p. 74), a literatura é, imediatamente, 
[...] a representação de homens singulares e de vivências singulares, que devem se referir às relações sociais da época somente em última instância, e tampouco devem revelar necessariamente uma conexão direta com o contraste burguesia e proletariado.

O verdadeiro conhecimento da realidade assume a forma de um movimento, de acordo com Lukács (1965, p. 57), que esclarece a unidade orgânica que liga a normalidade à exceção. É importante entender a importância do movimento para compreender que a verdade dos destinos humanos individuais é, também, a verdade do processo social. Essa verdade se revela na prática, na ação, na práxis.

As palavras dos homens, seus pensamentos e sentimentos puramente subjetivos, revelam-se verdadeiros ou não verdadeiros, sinceros ou insinceros, grandes ou limitados, quando se traduzem na prática, isto é, quando os atos e as forças dos homens confirmam-nos ou desmentem-nos na prova da realidade. Só a práxis humana pode exprimir concretamente a essência do homem (LUKÁCS, 1965, p. 56).

A centralidade da ação é, portanto, nesse sentido, ressaltar que o que importa aos homens é ver como outros homens reagem diante dos acontecimentos de suas vidas. $\mathrm{O}$ enredo precisa, sob pena de se tornar vazio, exprimir as relações orgânicas entre "[...] os homens e o mundo exterior, as coisas, as forças naturais e as instituições [...]" (LUKÁCS, 1965, p. 58). Tal é a importância da narração como método de composição, e, para além dele, escolha perante a vida, advertindo para o fato de que não há fenômenos literários puros; a descrição, então, deve dar suporte à ação, não ganhar autonomia dentro da obra.

A análise de Lukács é post festum, portanto, não objetiva tornar-se uma receita a ser seguida, inclusive, porque os escritores respondem às necessidades de seu tempo e situação histórica. Desta análise, ele extrai linhas gerais para a produção de obras de arte que alcancem o mesmo patamar da criação dos grandes escritores realistas do passado e de seu tempo e, ao mesmo tempo, rechaça aqueles em que as obras deformam a realidade. Se o homem quer ver clara imagem de sua práxis social, os personagens constituem sempre o principal. Fundamental expor algumas características dessa centralidade da ação.

O único modo adequado de representar a relação real do homem com a sociedade e a natureza é a figuração da ação (LUKÁCS, 2011, p. 205), pois o homem, ao agir na sua vida cotidiana, na realidade, como um ser social, expressa sua verdadeira essência. $O$ talento do escritor consiste em criar um enredo para proporcionar ao personagem revelar essa essência, daí a necessidade de o escritor conhecer a realidade que está figurando.

A seleção entre o que é essencial e o que é supérfluo só pode ser feita quando se tem uma visão de conjunto, ou seja, quando se chega ao final. $O$ escritor só pode tornar claro, em sua composição, o que é essencial porque a práxis, a história já o fez, a vida hierarquiza as coisas. 'O caráter 'passado' da epopeia, portanto, é um meio de composição fundamental, prescrito pela própria realidade ao trabalho de articulação e ordenamento da matéria" (LUKÁCS, 1965, p. 63). 
O autor onisciente, ou seja, conhecedor de todas as determinações e possibilidades do enredo, pode apresentar ao leitor, que desconhece o final, os elementos essenciais ao desenvolvimento da ação.

Mas o leitor é guiado pelo autor através da variedade e multiplicidade de aspectos do entrecho, e o autor, na sua onisciência, conhece o significado especial de cada particularidade, por menor que seja, sua ligação à solução definitiva, sua conexão com o desenvolvimento conclusivo dos caracteres, e só Ihe interessam as particularidades que podem servir para a realização da trama e para o desdobramento da ação no sentido de suas conclusões finais. A onisciência do autor dá segurança ao leitor e permite que este se instale familiarmente no mundo da poesia (LUKÁCS, 1965, p. 63).

Citando a novela Depois do baile, de Tolstoi, Lukács destaca que a grandeza da arte épica consiste no fato do autor russo manter a unidade na tensão. Tal tensão existe na arte quando concerne aos destinos humanos.

\begin{abstract}
A tensão não consiste, sem dúvida, na curiosidade estética de ver como o poeta se desincumbirá da tarefa prefixada. Consiste, isso sim, naquela curiosidade bem humana de saber que iniciativas deverá tomar Ulisses e que obstáculos deverá ainda superar para chegar a uma meta que já conhecemos (LUKÁCS, 1965, p. 65).
\end{abstract}

A criação da tensão está estreitamente ligada à criação de enredos que possuem como centro o homem, um homem que toma decisões e enfrenta situações que surgem na sua vida cotidiana. A curiosidade bem humana de que fala Lukács é, justamente, o interesse em ver refletida na arte a vida humana de cada um. Não há sentido nela se não reflete destinos humanos. Observe-se que a questão da tensão não se refere apenas à descoberta do fim do enredo, mas as diversas mediações que levarão os personagens a esse fim.

A contraposição entre o narrar e o descrever é um dos pilares do realismo lukacsiano, mas Lukács não está prescrevendo uma fórmula. Ele vê uma situação históricoconcreta, a produção literária de sua época e, em conformidade com a análise de Marx da decadência ideológica pós-1848, analisa os escritores em comparação com a época da produção burguesa de transição ao capitalismo, na qual a realidade social era figurada com maestria, desde que o escritor se comprometesse com a realidade.

Diferentemente do que acontece na narração, na qual se descrevem aspectos e coisas que tenham função concreta em acontecimentos humanos, a descrição como método central da composição descreve situações estáticas, isoladas, natureza morta. Uma descrição morta, segundo Lukács (1965, p. 66), implica a perda de significação íntima das coisas. No estilo descritivo, desaparecem as conexões épicas. "A descrição rebaixa os homens ao nível das coisas" (LUKÁCS, 1965, p. 73). "O método descritivo acarreta a monotonia compositiva, enquanto a arte da narração não só permite como estimula uma infinita variedade de formas de composição" (LUKÁCS, 1965, p. 81). A descrição sacrifica, de acordo com Lukács (1965, p. 91), todas as tensões. 
O método narrativo não pode abrir mão de representar o intrincado caminho que os indivíduos, conscientes ou não, percorrem e realizam em suas vidas singulares, o universal, o tipo; outro aspecto da discussão literária de Lukács é, justamente, a figuração de personagens típicos. A tipicidade só existe quando o personagem vive, em suas tramas pessoais, problemas gerais de sua época, revelando as múltiplas conexões entre o individual e o universal.

O personagem é típico não porque é a média estatística das propriedades individuais de um certo estrato de pessoas, mas porque nele - em seu caráter em seu destino - manifestam-se as características objetivas, historicamente típicas de sua classe; e tais características se expressam, ao mesmo tempo, como forças objetivas e como seu próprio destino individual (LUKÁCS, 2011, p. 211).

A tipicidade não é a representação de um ponto médio, artificialmente representado, mas a criação de destinos humanos que encarnem as contradições fundamentais da sociedade; segundo Lukács (2011, p. 208), a criação de personagens típicos é a figuração concreta das formas socais. Tais formas, na sociedade burguesa, expressam a dualidade de classes, pois cada ser singular representa um lugar, uma posição nas classes em luta.

O personagem típico o é em contraste com os demais personagens, "[...] fique claro que o comportamento extremo de um homem numa situação levada ao extremo exprime os mais profundos contrastes de um determinado complexo de problemas sociais" (LUKÁCS, 2010, p. 196). O autor quer explicar que a vivacidade dos grandes e inesquecíveis personagens se deve justamente a sua tipicidade.

Tal categoria foi desenvolvida, também, dos apontamentos de Engels que, em carta a Margaret Harkness", afirmou: "O realismo implica, a meu ver, além da verdade dos detalhes, a fiel reprodução de personagens típicos em situações típicas" (ENGELS apud LUKÁCS, 2010, p. 44). Para que esse caráter típico se efetive, de acordo com Lukács (2010, p. 188), é preciso que os personagens sejam representados no conjunto das relações que os ligam, desta forma, os personagens devem expressar sua própria concepção de mundo que é, segundo o filósofo húngaro, a mais elevada forma de consciência.

A concepção do mundo é a mais elevada forma de consciência; por isso, o escritor que a ignora suprime o aspecto mais importante do personagem que pretende criar. A concepção do mundo é uma profunda experiência pessoal do indivíduo singular, uma expressão altamente característica de sua íntima essência, e reflete ao mesmo tempo os problemas gerais da época (LUKÁCS, 2010, p. 189).

\footnotetext{
${ }^{1}$ Margaret Harkness foi uma escritora inglesa da década de 1880 que enviou uma carta a Engels juntamente a um de seus romances, $A$ city girl, solicitando uma avaliação crítica. Escrevia sob o pseudônimo de John Law (MARX; ENGELS, 2010).
}

Dialektiké, v. 1, 2016. p. 98-119 
A fisionomia intelectual é a expressão do modo pessoal do personagem de viver a universalidade, não são ideias objetivamente exatas nem significa que o personagem tenha pleno domínio sobre elas. O exemplo de Lukács, acerca dos personagens shakespearianos, Cassius e Brutus² é é longo, porém elucidativo.

Tomemos, como segundo termo de comparação, um dos muitos traços com os quais Shakespeare caracteriza seus heróis. Brutus é estoico, Cassius é epicurista. Shakespeare refere-se à circunstância apenas em poucas frases, aludindo muito pouco a ela. E, não obstante, o estoicismo de Brutus liga-se profundamente a toda sua existência: sua mulher, Pórcia, é filha de Catão, e todo o amor entre eles é impregnado, sem que isto seja expressamente evidenciado, de motivos afetivos e filosóficos extraídos do estoicismo romano. E são muito sintomáticos de seu gênero particular de estoicismo o comportamento confiante e idealista de Brutus, bem como sua oratória intencionalmente privada de ornamentos e alheia a toda pompa retórica. As mesmas considerações valem para o epicurismo de Cassius. Basta aduzir um só traço extremamente penetrante e profundo: Cassius, a quem suas concepções epicuristas tornam tão forte e inflexível, renega - no momento em que a trágica derrota da revolução se faz previsível e em quem tudo anuncia o fracasso iminente da última sublevação republicana - seu ateísmo epicurista e começa a crer nos presságios e profecias que Epicuro sempre ironizara (LUKÁCS, 2010, p. 190-191).

Shakespeare não gasta páginas descrevendo a concepção de mundo dos seus personagens, mas faz com que, em sua vida cotidiana, em suas ações essa concepção fique evidente, não de maneira forçada, mas como parte da constituição individual do personagem. Não há contradição entre a existência pessoal do personagem e sua concepção de mundo. Mesmo que o personagem proferisse uma concepção à qual não se vincula efetivamente, esse falseamento seria percebido na práxis cotidiana do personagem. A fisionomia intelectual é, então, perceptível nos personagens típicos.

O artista deve criar situações específicas para homens determinados e, através deles, as paixões individuais transcendem os limites do puramente pessoal. Não há uma privação do que é individual, mas é sua intensificação que o faz alcançar a tipicidade. 0 personagem deve ter condições de se elevar ao nível da generalização; a relação entre o universal e o individual precisa ser forte, pois, se essas ligações forem deficientes, não haverá típico, apenas uma abstração vazia. Tudo isso ocorre numa composição literária, na qual:

O enredo, como síntese concreta dessas ações e reações complexas na práxis dos homens; o conflito, como forma fundamental dessas ações e reações contraditórias; o paralelismo e o contraste, como expressões da direção - convergente ou antitética - na qual operam as paixões humanas: todos os princípios da composição poética não fazem mais do que refletir,

\footnotetext{
${ }^{2}$ Lukács se refere a tragédia Júlio Cesar, de Shakespeare.
} 
concentrando-se no filtro da síntese literária, as formas mais universais e necessárias da própria vida humana (LUKÁCS, 2010, p. 191).

A hierarquização das personagens como elemento compositivo auxilia na formação da fisionomia intelectual da personagem, de acordo com Lukács (2010, p. 193), o personagem protagonista deve conter, perante os demais, um grau de consciência maior sobre seu destino, deve procurar superar as determinações imediatas da realidade, eliminando uma atitude de apatia diante da vida e atuando conscientemente em sua história. Se o escritor reflete a realidade como um mundo imutável, certamente, seu protagonista não terá a força necessária para alcançar a genericidade. Desta forma, é essencial recordar que o reflexo da realidade objetiva é fundamental, inclusive, nesse processo de hierarquização das personagens, pois é ela quem seleciona o que é essencial e o que é supérfluo no enredo.

A escolha dos personagens e seu lugar na narrativa não é uma tarefa completamente subjetiva, mas é um problema concreto. Importante ressaltar, com Lukács (2010, p. 195), que há uma dependência entre as exigências da composição literária e o reflexo da realidade objetiva, recaindo, as soluções dos problemas surgidos na composição, na escolha do artista entre o participar e o observar.

Lukács (2010, p. 195) explica que, para que se tenha necessidade de elaborar uma fisionomia intelectual, é preciso ter um conceito elevado do típico. "A figuração da fisionomia intelectual pressupõe, portanto, uma caracterização dos personagens que seja extremamente ampla, profunda e universal" (LUKÁCS, 2010, p. 195). Ao escritor cabe conhecer profundamente a realidade para superar o mero cotidiano e elevar seu personagem a uma situação típica.

O profundo conhecimento da vida jamais se limita à observação da realidade cotidiana, mas consiste, ao contrário, na capacidade de captar os elementos essenciais, bem como de inventar, sobre tal fundamento, personagens e situações que sejam absolutamente impossíveis na vida cotidiana, mas que estejam em condições de revelar, à luz da suprema dialética das contradições, as tendências e forças operantes, cuja ação é dificilmente perceptível na penumbra da vida de todos os dias (LUKÁCS, 2010, p. 196).

Os personagens e as situações são típicos mediante a superação da vida cotidiana, pois elas expressam os mais profundos contrastes de um determinado complexo de problemas e situações de um dado momento histórico.

Outra função atribuída por Lukács $(2010,198)$ à fisionomia intelectual é a de tonar sensível a relação com as demais situações extraordinárias representadas na obra. Por meio do contraste que a tipicidade cria, ao expor os casos individuais ao lado dos demais casos da obra, é possível fazer a conexão entre o individual e o universal, tendo em vista que a comparação dos contrastes clareia o entendimento das coisas. O filósofo magiar enuncia o que, para ele, é o segredo da grande arte de figurar os personagens "o homem inteiro deve se mover inteiramente de uma vez só”. (EMERSON apud LUKÁCS, 2010, p. 229). 
O alto nível espiritual do herói, que se eleva à lúcida consciência o próprio destino, é necessário sobretudo para retirar às situações a sua excepcionalidade, expressando assim o elemento universal sobre o qual elas se apoiam, o qual é a manifestação dos contrastes em seu estágio mais alto e mais puro (LUKÁCS, 2010, p. 197).

A identificação do receptor de uma obra de arte com o típico figurado nela ocorre porque a vida individual e a vida genérica do homem não são distintas, mesmo que, necessariamente, a existência individual seja um modo particular de vida genérica. A dialética universalidade, singularidade e particularidade não foi, nem poderia ser, aprofundada neste estudo, mas, nas iniciais leituras acerca dessa dialética, para tratar da relação entre a obra literária e seu caráter típico com a genericidade parece importante aduzir, brevemente, a isso.

No contexto destas controvérsias, a dialética de universal e particular na sociedade tem uma função de grande monta; o particular representa aqui, precisamente, a expressão lógica das categorias de mediação entre os homens singulares e a sociedade (LUKÁCS, 1978, p. 93).

O universal, segundo Lukács (1978), é uma abstração realizada pela própria realidade. 0 singular e o universal são uma unidade dialética. Para explicar isso, ele cita a análise de Lenin sobre a lógica de Aristóteles que destaca a conexão contraditória entre singular e universal:

Começando com uma locução qualquer, das mais simples, correntes e de maior emprego, etc.: "as folhas da árvore estão verdes"; "Ivan é um homem"; "Zhuchka é um cachorro", etc. Já aqui 9como Hegel o assinalava genialmente) há dialética: o singular é o universal... Dessa forma, os opostos (o singular é o oposto do universal) são idênticos: o singular não existe senão em sua relação com o universal. 0 universal só existe no singular, através do singular. Todo singular é (de um modo ou de outro) universal. Todo universal é (partícula ou aspecto, ou essência) do singular. Todo universal abarca, apenas de um modo aproximado, todos os objetos singulares. Todo singular faz parte, incompletamente, do universal, etc. Todo singular está ligado, por meio de milhares de transições, aos singulares de um outro gênero (objetos, fenômenos, processos), etc. Já aqui há elementos, germes, do conceito da necessidade, da relação objetiva da natureza, etc. (LUKÁCS, 1978, p. 109).

O particular é elemento mediador entre o universal e o singular, não de forma pontual, como um ponto médio, mas como um campo de mediação. Lukács (1978, p. 116117) adverte para a polissemia linguística do termo "particularidade" que ora significa o que impressiona, salta à vista, ora tem sentido daquilo que é específico e, em filosofia, como 
sinônimo de determinado. O destaque recai, segundo ele, no caráter posicional da particularidade, "[...] isto é, ao fato de que ela, com relação ao singular, representa uma universalidade relativa, e, com relação ao universal, uma singularidade relativa" (LUKÁCS, 1978, p. 117). Essa relatividade posicional reforça o caráter processual da particularidade.

No reflexo estético, no entanto, o termo intermediário torna-se o ponto do meio para o qual os movimentos convergem.

Neste caso, portanto, existe um movimento da particularidade à universalidade (e vice-versa), bem como da particularidade à singularidade (e ainda vice-versa), e em ambos os casos o movimento para a particularidade é o conclusivo (LUKÁCS, 1978, p. 161).

Sobre a particularidade se funda o mundo formal das obras de arte, e ela se manifesta de forma autônoma, sendo a forma autônoma da particularidade algo criado pelo homem que não pretende ser uma realidade da mesma forma que é a realidade objetiva; ela se coloca diante do receptor como uma realidade, porém a da obra é uma realidade sensível. Somente se pode elevar uma singularidade ao nível do particular acentuando-se a sua sensibilidade imediata (LUKÁCS, 1978, p. 176-177). Disto decorre que

A forma autônoma da obra, portanto, é um reflexo de nexos e de formas fenomênicas essenciais da própria realidade. Precisamente por isto, e apenas por isto, a obra pode se apresentar a nós como forma autônoma: porque, deste ponto de vista, ela reflete fielmente a estrutura da realidade objetiva (LUKÁCS, 1978, p. 177).

Com a representação do particular na obra de arte, o mundo da obra é o mundo humano refletido. A durabilidade de certos enredos e personagens baseia-se, justamente, neste ponto: mesmo que se trate do passado, de um momento histórico superado, os dramas humanos ali vividos fazem parte da história da humanidade, da infância, como disse Marx; não é a vida passada pessoal de cada indivíduo, mas o passado do indivíduo como ser pertencente à humanidade, ao gênero humano.

Nisto se apresenta a identificação do homem com a arte, ou seja, a percepção da genericidade: na identificação dos indivíduos singulares com as grandes obras que figuram os destinos humanos que são, ao mesmo tempo, destinos da humanidade. Em suas conversas com Holz, Kofler e Abendroth (1969), Lukács ressalta esse caráter da literatura ao afirmar que as obras que se conservam são aquelas que se relacionam com o desenvolvimento da humanidade. O reflexo estético da realidade representa casos singulares, únicos e, mediante a intensificação de sua singularidade, expressam as mediações, as grandes relações da vida.

O verdadeiro conteúdo desta generalização, que aprofunda e enriquece objetiva e subjetivamente a individualidade, mas sem jamais conduzi-la 
para fora de si mesma, é precisamente o caráter social da personalidade humana (LUKÁCS, 1978, p. 291).

Alguns críticos de Lukács afirmam que o filósofo magiar faz apologia à arte de propaganda. Na verdade, ele combate tanto a teoria de que é papel da arte e da literatura fazer apologia a uma corrente social por mais avançada que seja, quanto a teoria de que elas são completamente autônomas. Não há obra de arte imparcial.

Lukács (2010) está convencido de que o que retirou a liberdade do artista moderno foi, justamente, a ilusão de total autonomia "conquistada" no capitalismo. Quanto mais a sociedade capitalista desenvolve essa falsa liberdade, torna-a servidão. Tudo é entregue ao artista, mas este não percebe a sociedade como ela é e, diferentemente do artista da Antiguidade, que sabia a quem dirigia suas obras e que conhecia a relação delas com a sociedade em que vivia, mesmo de forma inconsciente, o artista moderno é um produto da divisão capitalista do trabalho.

Vale a pena mencionar o problema da perspectiva. Essa questão aparece brevemente desenvolvida no texto da intervenção feita por Lukács no IV Congresso dos Escritos Alemães, em Berlim, a 11 de janeiro de 1956, no qual ele afirma que são muitos os problemas da figuração da perspectiva, dentre eles, o resultado do esquematismo da literatura de sua época, que figura a perspectiva de maneira mecânica ou a deforma, nesse mecanicismo.

Nos demais textos estudados, o problema da perspectiva não foi tratado tão claramente, mas, como se poderá perceber, ele aparece implícito nas teorizações estéticas lukacsianas; impossível não pensar, retroativamente, nessa questão, quando Lukács se refere à concepção de mundo e à fisionomia intelectual, por exemplo, categorias que parecem permeadas pela perspectiva, pois elas apontam um devir.

De acordo com Lukács (2010, p. 187-188), a perspectiva pode ser definida, em primeiro lugar, quando uma coisa ainda não é existente; em segundo lugar, mesmo não existindo, ela não é simplesmente uma utopia, mas uma consequência necessária da evolução social objetiva "[...] que se manifesta objetivamente, no plano literário, através do desenvolvimento de uma série de personagens agindo em determinadas situações" (2010, p. 287); por último, ela é objetiva, mas não fatalista, ou seja, ela é uma tendência que pode se realizar a depender das ações dos homens. "Trata-se de uma grande tendência social, que se realiza por caminhos intrincados, talvez de um modo muito diferente do que aquele que imaginamos" (LUKÁCS, 2010, p. 287).

O enredo, a ação de uma obra literária se desenvolve até certo ponto; onde deveria ser seu ponto final não é um fim em sentido estrito, há um futuro posterior ao fim do romance. A perspectiva é erroneamente figurada se essa tendência para o futuro for inserida na narrativa de fora, não emergindo do próprio desenvolvimento concreto dos indivíduos figurados na obra de arte.

Lukács (2010) se questiona, então, quanto de perspectiva deve ser figurado. A resposta não poderia ser outra: vai depender da obra e, respeitar a realidade nela refletida, suas leis e tendências próprias do mundo representado. Segundo o autor, isso se dá porque a obra literária só corresponde a um pedaço da evolução histórica, portanto, não pode 
prever futuros muito longínquos, os quais o enredo não alcança, sob pena de cair numa perspectiva idealmente inserida, na obra. Isso vale para o realismo socialista, também.

\begin{abstract}
Por isso, toda simplificação, toda subestimação das dificuldades que se erguem diante de nós, toda superestimação dos resultados que podemos obter num determinado momento, levam a que se represente como atualmente existente na realidade o que somente é verdadeiro e real como perspectiva (LUKÁCS, 2010, p. 290).
\end{abstract}

Lukács é enfático ao dizer que, por mais que sejam louváveis os motivos do esquematismo, ele faz com que a obra passe de otimista real ao otimismo banal, ao que ele chama de happy end, ou seja, um final feliz sem quaisquer fundamentos, sem uma relação com as situações retratadas, um final feliz vazio de sentido.

A realidade, segundo Lukács (2010, p. 291), é muito mais eficaz em encontrar saídas para os problemas concretos do que quaisquer ideias que possam ser teoricamente formuladas. O papel da literatura verdadeiramente grande e da criação de seu escritor é revelar, por meio dos destinos que figura, esse poder da realidade. A literatura vale muito, para Lukács (2010), quando apresenta um passo real do movimento histórico-concreto. Às obras que não alcançam esse entendimento restam os cemitérios da história.

Porque a realidade segue seus caminhos independentemente do pensamento, independentemente dos escritores; e, se o escritor não logrou representar corretamente um único passo real (é por isso que falei de modéstia da perspectiva), se deu cinco passos errados enquanto a realidade dava seus cinco passos justos, então o homem que foi representado desta maneira continua a viver apenas como um fantasma. A obra assim criada envelhece totalmente (LUKÁCS, 2010, p. 291).

Esse debate da perspectiva é muito caro aos escritores revolucionários e merece um estudo não apenas teórico, mas crítico-literário, que não se pode fazer aqui, mas apresentar, mesmo de uma forma geral, os pontos a serem aprofundados na teoria literária de Lukács é, certamente, o propósito deste trabalho.

\title{
3 O ENSINO DE LITERATURA NO BRASIL: APONTAMENTOS CRÍTICOS
}

Há, ainda, que se compreender a educação em suas duas dimensões: em sentido amplo ou educação lato sensu, ela se caracteriza por transmitir aos novos indivíduos a humanidade socialmente construída, portanto não se restringe à escola, assim como a linguagem e o conhecimento, é inseparável do trabalho, é universal; já a educação formal ou stricto sensu, desenvolvida nas instituições formais, como a escola, é característica de cada modelo de sociedade, por isso historicamente situada e não universal (SAVIANI, 1994). 
A arte e a literatura, também, possuem uma especificidade própria, portanto elas exercem sua contribuição para a formação do homem, na sociedade, internamente, ou seja, a fragmentação dos objetos artísticos e literários colocados a serviço da educação fragmentária burguesa deforma o papel delas na vida humana. Arte e literatura precisam exercer seu papel específico e, para tanto, precisam de condições específicas; o que implica, como no caso da educação, na manutenção e ampliação das conquistas educacionais da classe dos trabalhadores.

As Diretrizes Curriculares para o Ensino Médio (BRASIL, 2000) estabeleceram, com vistas a fomentar uma formação interdisciplinar e contextualizada como princípios estruturadores do currículo, áreas do conhecimento que passariam a organizar as competências e as habilidades elencadas como necessidades na Lei de Diretrizes e Bases da Educação Nacional (LDBEN 9394/96). Assim, os princípios axiológicos foram propostos a atender a demanda quanto a: a) fortalecimento dos laços de solidariedade e de tolerância recíproca; b) formação de valores; c) aprimoramento como pessoa humana; d) formação ética; e) exercício da cidadania.

Desta forma, pode-se destacar que os princípios que norteiam as diretrizes curriculares estão estreitamente vinculados à formação do homem para a sociedade burguesa, do cidadão, da formação de valores historicamente situados no contexto da sociedade de classes. O conhecimento e os valores que contestariam essa realidade, a formação crítica não é apresentada pelo documento como um princípio norteador.

Sobre a área de Linguagens, códigos e suas tecnologias (LC), as DCNs afirmam:

\begin{abstract}
As escolas certamente identificarão nesta área as disciplinas, atividades e conteúdos relacionados às diferentes formas de expressão, das quais a Língua Portuguesa é imprescindível. Mas é importante destacar que o agrupamento das linguagens busca estabelecer correspondência não apenas entre as formas de comunicação - das quais as artes, as atividades físicas e a informática fazem parte inseparável - como evidenciar a importância de todas as linguagens enquanto constituintes dos conhecimentos e das identidades dos alunos, de modo a contemplar as possibilidades artísticas, lúdicas e motoras de conhecer o mundo. A utilização dos códigos que dão suporte às linguagens não visa apenas ao domínio técnico, mas principalmente à competência de desempenho, ao saber usar as linguagens em diferentes situações ou contextos, considerando inclusive os interlocutores ou públicos (BRASIL, 2000, p. 92).
\end{abstract}

Na descrição dos conteúdos da área de LC não há menção à literatura. O destaque é dado ao conhecimento das várias formas de comunicação e à importância de conhecê-las para se comunicar eficazmente na sociedade. A descrição das competências desta área é muito genérica, não se dá ênfase aos aspectos diretamente ligados às verdadeiras questões de linguagem.

O documento governamental que melhor discute o problema aqui tratado é o que expressa as Orientações Curriculares para o Ensino Médio: linguagens, códigos e suas tecnologias - OCEM (BRASIL, 2006), especificamente a parte que trata do ensino de 
literatura. O uso desse documento se justifica, primeiramente, pelo fato do ensino de literatura, no Brasil, ser obrigatório apenas para o ensino médio; além disso, os Parâmetros Curriculares Nacionais para o Ensino Médio - PCNs (BRASIL, 2002) não terem dedicado parte relevante ao ensino da disciplina de literatura, sob a justificativa de defender uma abordagem linguística interdisciplinar.

O capítulo que trata da literatura divide-se em quatro partes. A primeira reflete sobre o papel da literatura no Ensino Médio; o segundo discorre sobre a formação do leitor no Ensino Fundamental e no Ensino Médio, em seguida, discute-se o que é e como se dá a leitura literária, e, por fim, apresentam-se possibilidades de mediação para o ensino da literatura na escola. Como se pode ver, corrigindo a ausência da literatura nas DCNs e nos PCNs, as OCEM tratam o tema com maior profundidade. Além disso, o presente estudo se justifica por ele se pretender indicar alternativas didático-pedagógicas na estruturação do currículo para o ensino médio, desta forma, ele almeja ser uma orientação padronizada nacionalmente e válida a todos os professores.

A demanda era pela retomada da discussão dos Parâmetros Curriculares Nacionais do Ensino Médio, não só no sentido de aprofundar a compreensão sobre pontos que mereciam esclarecimentos, como também, de apontar e desenvolver indicativos que pudessem oferecer alternativas didático-pedagógicas para a organização do trabalho pedagógico, a fim de atender às necessidades e às expectativas das escolas e dos professores na estruturação do currículo para o ensino médio (BRASIL, 2006, p. 08).

Tais documentos explicitam os discursos hegemônicos sobre o ensino de literatura, bem como das demais disciplinas do currículo que direcionam a educação básica brasileira. Além disso, toda prática pedagógica possui implícita ou explicitamente uma fundamentação, uma concepção de mundo, de homem e de sociedade, por exemplo. A questão a ser discutida tem como pressuposto o conhecimento da natureza da educação na sociedade burguesa, entendendo, com Tonet (2013, p. 231), que grande parte da realidade social, hoje, é organizada pela classe dominante e que, por isso, uma atividade de caráter emancipador não pode chegar a ser uma política do Estado brasileiro, sequer ter um caráter sistemático.

O discurso hegemônico destaca que, na escola, o aluno deve ser levado ao desenvolvimento da percepção estética e do pensamento artístico; ter estimulada sua sensibilidade e imaginação; conhecer as formas produzidas historicamente. O papel da escola seria dotar o educando de condições para se relacionar com o texto literário. Depois, o objetivo volta-se para a formação crítica do cidadão consciente de seu papel na sociedade.

O texto do documento inicia com uma breve e superficial discussão acerca das categorias arte, trabalho e literatura. Arte e trabalho se opõem, na definição do documento, pois este estaria ligado ao sofrimento e aquela ao prazer, à suspensão do sofrimento causado pelas péssimas condições de trabalho a que são submetidos os homens nessa sociedade. Não há menção às causas desse sofrimento gerado no trabalho. Leia-se a citação de Jauss (BRASIL, 2006, p. 51) apresentada no documento. 
[...] por um lado, prazer e trabalho formam, de fato, uma velha oposição, atribuída desde a Antiguidade ao conceito de experiência estética. À medida que o prazer estético se libera da obrigação prática do trabalho e das necessidades naturais do cotidiano, funda uma função social que sempre caracterizou a experiência estética. Por outro lado, a experiência estética não era, desde o princípio, oposta ao conhecimento e à ação (Grifo nosso).

A dicotomia utilidade-inutilidade, superada pela estética lukacsiana, está aqui expressa como uma verdade da realidade objetiva e da essência desses dois complexos sociais. Não aparece uma contraposição a essa definição, nem à contraposição prazer, ligado à arte, e sofrimento, relacionado ao trabalho. Ao contrário, os autores do texto compreendem que essa oposição justifica a necessidade da arte e da literatura na escola, pois abranda as consequências de uma formação voltada para o trabalho.

Essa compreensão escamoteia a essência da arte que aparece como um produto de gozo e que se opõe ao trabalho e mistifica sua essência que aparece como gerador de alienação e sofrimento. As consequências dessa concepção são sérias do ponto de vista da (de)formação do homem e da reprodução social, bem como para a atividade do professor que reproduzirá nos alunos essa concepção de homem, de mundo e de sociedade. Trabalho para as OCEM equivale a trabalho alienado, mas ele ganha status de essência.

Tal como afirma a Mãe, embora condenando essa função, a arte "inventa uma alegriazinha", rompe com a hegemonia do trabalho alienado (aquele que é executado pelo trabalhador sem nele ver outra finalidade senão proporcionar o lucro ao dono dos modos de produção), do trabalho-dor (BRASIL, 2006, p. 52, Grifo nosso).

E a consequência, dita acima, aparece em seguida:

Nesse mundo dominado pela mercadoria, colocam-se as artes inventando "alegriazinha", isto é, como meio de educação da sensibilidade; como meio de atingir um conhecimento tão importante quanto o científico - embora se faça por outros caminhos; como meio de pôr em questão (fazendo-se crítica, pois) o que parece ser ocorrência/decorrência natural; como meio de transcender o simplesmente dado, mediante o gozo da liberdade que só a fruição estética permite; como meio de acesso a um conhecimento que objetivamente não se pode mensurar; como meio, sobretudo, de humanização do homem coisificado: esses são alguns dos papéis reservados às artes, de cuja apropriação todos têm direito. Diríamos mesmo que têm mais direito aqueles que têm sido, por um mecanismo ideologicamente perverso, sistematicamente mais expropriados de tantos direitos, entre eles até o de pensar por si mesmos (BRASIL, 2006, p. 52-53, Grifos nossos). 
A arte recebe uma aura transcendente ao ser oposta à realidade imanente reificada. Alcançar a superação da realidade, nestes termos, é uma impossibilidade total, daí a importância da arte, pois o que é possível, nessa sociedade, é suspender momentaneamente essas deformações e alcançar efemeramente a sensação de liberdade. A estética, novamente, se afasta do movimento do real. Não se busca compreender a arte por suas conexões imanentes, ao contrário, ela é posta como um objeto tão sublime que não pode fazer parte de uma realidade reificada.

O objetivo, então, do ensino de literatura é formar o leitor literário, "letrar" literariamente o individuo para que ele tenha as ferramentas necessárias para desfrutar do prazer estético proporcionado pela literatura, do qual ele tem direito. As OCEM partem do conceito de letramento, tomado de empréstimo da linguística, e definido como sendo "[...] estado ou condição de quem não apenas sabe ler e escrever, mas cultiva e exerce as práticas sociais que usam a escrita" (SOARES apud BRASIL, 2006, p. 54-55). O letramento literário seria, por extensão, "[...] estado ou condição de quem não apenas é capaz de ler poesia ou drama, mas dele se apropria efetivamente por meio da experiência estética, fruindo-o" (BRASIL, 2006, p.55).

Segue a advertência sobre o prazer estético, demonstrando que as definições são demasiado falhas ao ponto de se relativizarem:

O prazer estético é, então, compreendido aqui como conhecimento, participação, fruição. Desse modo, explica-se a razão do prazer estético mesmo diante de um texto que nos cause profunda tristeza ou horror [...] (BRASIL, 2006, p. 55).

As definições de arte e literatura apresentadas no documento são baseadas em recentes estudos e não são completamente errôneas, ao contrário, é possível encontrar aspectos positivos, mas não se pode perder de vista que há uma disparidade entre o discurso governamental e a prática docente, baseada nele. Baseado nos estudos de Antônio Cândido, o documento destaca o papel da literatura no processo de humanização. Leia-se:

Entendo aqui por humanização [...] o processo que confirma no homem aqueles traços que reputamos essenciais, como o exercício da reflexão, a aquisição do saber, a boa disposição para com o próximo, o afinamento das emoções, a capacidade de penetrar nos problemas da vida, o senso da beleza, a percepção da complexidade do mundo e dos seres, o cultivo do humor. A literatura desenvolve em nós a quota de humanidade na medida em que nos torna mais compreensivos e abertos para a natureza, a sociedade, o semelhante (CÂNDIDO apud BRASIL, 2006, p. 54).

Assim, a literatura é definida da seguinte forma:

Boa parte da resposta pode ser encontrada talvez no próprio conceito de Literatura tal como o utilizamos até aqui, isto é, em seu sentido mais 
restrito. Embora se possa considerar, lato sensu, tudo o que é escrito como Literatura (ouve-se falar em literatura médica, literatura científica, etc.), para discutir o currículo do ensino médio tomaremos a Literatura em seu stricto sensu: como arte que se constrói com palavras (BRASIL, 2006, p. 52).

As Orientações Curriculares avançam em relação aos Parâmetros Curriculares, pois discutem os pontos nos quais este estava equivocado, dentre eles, foco nos estudos históricos da literatura, destaque demasiado no interlocutor e entendimento de fruição estética apenas como divertimento. Tais procedimentos pedagógicos têm norteado historicamente o ensino da literatura no Brasil, desta forma, é um avanço do ponto de vista da política educacional brasileira elaborar um documento que, embora, não avance no sentido de destacar a função social da literatura como um objeto que deve permitir o conhecimento da essência social, vai além da aquisição dos conhecimentos fragmentários da história da literatura.

Entretanto, a prática não condiz com o estabelecido no documento. Na escola, o que permanece é o ensino tradicional de literatura e, para efeito de confirmação, basta analisar os livros didáticos indicados e escolhidos no Programa Nacional do Livro Didático (PNLD) pelas escolas públicas brasileiras que permanecem proporcionando um estudo, por mais contextualizado, que privilegia a aquisição de algum conhecimento sobre as escolas literárias e seus autores e pela cobrança conteudística do Exame Nacional do Ensino Médio (ENEM). Ao contrário do que define o documento das OCEM.

O livro didático, como lembramos anteriormente, pode constituir elemento de apoio para que se proceda ao processo de escolha das obras que serão lidas, mas de forma alguma poderá ser o único. Os professores devem contar com outras estratégias orientadoras dos procedimentos, guiando-se, por exemplo, por sua própria formação como leitor de obras de referência das literaturas em língua portuguesa, selecionando aquelas cuja leitura deseja partilhar com os alunos (BRASIL, 2006, p 64-65).

Interessante destacar que o documento pressupõe um tipo de leitor que não condiz com aquele encontrado nas escolas brasileiras, um ideal de leitor para o Ensino Fundamental e outro para o Ensino Médio e, partindo desse ideal, se estabelecem as diretrizes curriculares a serem seguidas. Não é de estranhar, portanto, que a teoria expressa nos documentos oficiais não condiga com a realidade. Segundo, as OCEM (BRASIL, 2006, p. 63) "[...] os alunos do ensino fundamental iniciam sua formação pela literatura infanto-juvenil, em propostas ficcionais nas quais prevalecem modelos de ação e de aventuras", já sobre o aluno do Ensino Médio

[...] supõe-se que os alunos que ingressam no ensino médio já estejam preparados para a leitura de textos mais complexos da cultura literária, que poderão ser trabalhados lado a lado com outras modalidades com as quais estão mais familiarizados como o hip-hop, as letras de músicas, os quadrinhos, o cordel, entre outras relacionadas ao contexto cultural menos 
ou mais urbano em que tais gêneros se produzem na sociedade. (BRASIL, 2006, p. 63).

O que se tentou expor aqui foi a disparidade entre o discurso governamental e a prática, tendo em vista que o professor de literatura é norteado por documentos do tipo dos Parâmetros e das Orientações Curriculares Nacionais e que estes, muitas vezes, são as únicas referencias desses professores que, durante sua formação acadêmica específica, não tiveram acesso a teorias mais avançadas do ponto de vista da análise do real, como a marxista e a lukacsiana, por exemplo.

A análise destes documentos apontou que as práticas sugeridas e os resultados a serem alcançados são importantes para o desenvolvimento estético dos indivíduos. Não se nega que formar um leitor deva ser norte importante para o trabalho escolar. Pensando-se a padronização desse estudo de forma isolada, apartada da realidade social, não há questionamento a ser feito quanto a ele:

Formar para o gosto literário, conhecer a tradição literária local e oferecer instrumentos para uma penetração mais aguda nas obras tradicionalmente objetivos da escola em relação à literatura - decerto supõem percorrer o arco que vai do leitor vítima ao leitor crítico. Tais objetivos são, portanto, inteiramente pertinentes e inquestionáveis, mas questionados devem ser os métodos que têm sido utilizados para esses fins (BRASIL, 2006, p. 69).

O discurso seria perfeito se não existisse um modelo social vigente a ser mantido e reproduzido pela escola. O cidadão ideal para essa sociedade é aquele que pensa nos limites da sociabilidade burguesa, sem questionar sua existência e buscar sua superação. A escola pública, tensionada e orientada, em última instância, pela lógica da produção e reprodução do capital, é, entretanto, o lugar no qual a educação estrita se realiza. Essa realidade deve ser levada em consideração, sob pena de executar uma política, uma metodologia e uma prática educacional desvinculada da realidade.

Conhecer os limites e as possibilidades do ato educativo é poder agir conscientemente em prol do avanço social para um novo tipo no qual os homens sejam verdadeiramente livres. A autonomia relativa dos complexos fundados em relação à base econômica torna possível realizar atividades, no seio da escola, que primem pela contribuição à luta da classe trabalhadora. Nesse sentido, o ensino da literatura pode auxiliar no processo, entretanto, é necessário questionar qual o tipo de ensino e o que se ensina sobre literatura.

Lukács (1982b) chama de desfetichização um conhecimento de algo que retransforma algo que é aparentemente coisa em uma relação entre homens. Desfetichizar é, portanto, apreender a essência das objetivações - e das relações - entre os homens, num duplo movimento: em primeiro lugar, desmascara a aparência falseadora que deforma a essência da realidade e; em segundo, retifica o papel dos homens na história. 
Por fetichização compreende um caráter amplo: "[...] la fetichización consiste en que - por motivos histórico-sociales diversos en cada caso- se ponen objetividades independientes en las representaciones generales, objetividades que ni en sí ni respecto de los hombres lo son realmente" (LUKÁCS, 1982b, p. 383). Deste modo, cabe à arte e, neste caso à Literatura, uma tendência desfetichizadora que não pode ser renunciada. A educação pode fazer uso de objetos de arte e de literatura para auxiliar no processo de formação do homem e, além, contribuir para a formação do homem crítico da sociedade capitalista, mesmo que o sucesso imediato não possa ser aferido.

\section{CONSIDERAÇÕES FINAIS}

Tentou-se esboçar aqui um panorama das principais categorias teóricas desenvolvidas por Lukács sobre a literatura. Importante ressaltar que o filósofo húngaro não escreveu uma obra sistemática sobre o assunto, portanto, as categorias extraídas de suas obras foram escolhidas, na leitura aqui realizada, por terem sido consideradas importantes para o objetivo deste trabalho.

Vale a pena advertir que, ao tratar de ensino, está-se levando em consideração que - lugar da educação, nesta sociedade, é a escola, considerando-se as duas dimensões da educação, as quais foram chamadas de educação lato sensu e stricto sensu, retomando a nomenclatura de Saviani (1994). As instituições burguesas nas quais o ensino ocorre são, portanto, os lugares onde a educação se efetiva na sociedade capitalista.

Sabe-se que a escola é um instrumento de reprodução da sociedade capitalista e de produção e reprodução do homem e do trabalhador ideal para esse tipo de sociedade. A instituição escola, filiada às leis, parâmetros, currículos direcionados pelo Estado é subordinada aos interesses de manutenção da ordem capitalista, expressas pelos objetivos traçados por organismos como o Banco Mundial, a UNESCO e a ONU que determinam como deve ser a educação de países periféricos. A adequação da educação strito sensu ao capital é evidente quando se observam as mudanças das políticas educacionais brasileiras na tentativa de se adequar às necessidades históricas da sociedade capitalista.

Ao mesmo tempo em que o papel majoritário da escola burguesa é de produção e reprodução do homem e trabalhador ideal para a sociedade capitalista, ela possui em seu seio um espaço de contradição. O complexo da educação se caracteriza por ser uma teleologia secundária, uma relação entre subjetividades, desta forma, há possibilidades de atuação pelos indivíduos que formam a escola de atividades que visem proporcionar uma formação voltada para os interesses da classe trabalhadora.

Além disso, o educando acessa, por meio da escola, conhecimentos e habilidades produzidos pela humanidade, ele acessa o patrimônio cultural humano. Ao mesmo tempo em que o Estado quer um trabalhador desconhecedor da realidade social, mantém instituições que podem gerar justamente o efeito contrário desejado. A coalizão de forças pelo sucateamento e abandono da educação pública pelo Estado é, justamente, uma tentativa de oferecer ao trabalhador apenas o mínimo necessário para exercer as funções esperadas pela classe operária, funções mal remuneradas e embrutecedoras. $O$ espaço de contradição permite alguma atuação, nesse cenário. 
Deste modo, é causa indispensável da classe trabalhadora como um todo e da brasileira, em particular, lutar pela manutenção e ampliação dos direitos conquistados no que tange à educação pública e de qualidade. A consciência dos limites e possibilidades da educação como instrumento de formação humana tanto em seu sentido amplo quanto em seu sentido estrito é fundamental para que se encontre uma terceira via às posições correntes acerca do assunto.

Esclarecido esse ponto, os elementos didáticos a serem apontados aqui dizem mais respeito à posição de Libâneo (2009) que entende a didática como uma relação mais ampla entre os elementos envolvidos no processo de ensino. Desta forma, serão destacadas as contribuições da concepção de literatura realista para a educação escolar como possibilidade de contribuição à formação da classe trabalhadora. Pensa-se que do ponto de vista de propor atividades práticas, o próprio professor pode planejar como atuar, parece mais urgente discutir os fundamentos dessa prática.

O professor de literatura lida com a literatura como matéria escolar de duas maneiras principais. Como um conhecimento científico da história do desenvolvimento da literatura, das características do texto, dos escritores e das escolas literárias; este é priorizado pelo currículo e pelos instrumentos de avaliação internos e externos à escola. Por outro lado, o professor lida com uma obra de arte que exerce uma função social, como demonstrado até aqui; o texto literário como uma objetivação humana. Em meio a essas questões, o professor precisa fazer escolhas práticas para que seus estudantes adquiram, além do exigido pelo currículo, experiências com a literatura.

Conciliar o trabalho docente do professor de literatura com essas duas necessidades parece ser o caminho de uma práxis de caráter emancipador (TONET, 2013). Proporcionar aos alunos, com ênfase na escola pública, os conhecimentos e habilidades necessários à fruição da obra literária que eleve sua consciência a outros patamares, enriquecendo sua compreensão da realidade, de si mesmo e dos homens, neste sentido, a educação proporcionada pela literatura se insere na educação lato sensu, ou seja, contribui para formação do homem como partícipe de um gênero. Não será possível discutir as deformações que uma obra literária pode gerar nos indivíduos, mas não se ignora aqui este fato, a escolha, entretanto, é acentuar aquelas que podem contribuir de forma positiva para a educação do homem.

Parece ser um ponto de partida escolher obras a serem lidas na integralidade com base na proximidade entre problemas vivenciados pelos estudantes e o enredo figurado na obra, como mecanismo de desenvolvimento do interesse dos alunos. Esse não pode ser, entretanto, um critério permanente, já que não há como afirmar que uma obra que trate de uma porção da realidade mais distante dos alunos não será compreendida. O importante é oferecer uma variedade de obras de qualidade estética e, em paralelo, desenvolver as habilidades para os estudantes entendê-las e muni-los dos conhecimentos históricos da literatura.

O processo de acompanhamento das leituras deve se sobrepor às avaliações quantitativas. A preocupação em checar se o aluno entendeu ou não determinados aspectos do texto lido não deve direcionar a atividade do professor, tendo em vista que não é possível garantir a eficácia pedagógico-social de determinada obra literária. Mesmo que as fichas de leitura tenham sido abolidas como metodologia de avaliação de leitura, ainda se está preso a métodos mecanicistas de avaliação, como provas e seminários. Deixar fruir a leitura pode ser 
bem mais proveitoso para o aluno. O efeito pode não ser o desejado pelo docente, mas a relação estabelecida entre leitor e livro é pessoal.

Há muito se tem falado em interdisciplinaridade nas discussões educacionais. 0 conceito já se tornou "palavra de moda", mas, efetivamente, o ensino permanece fragmentado. Vale a pena ao professor de literatura, compreender o caráter interdisciplinar do reflexo artístico, no sentido de que ele apresenta todas as mediações necessárias para aquela porção de realidade refletida. Ao compreender desta forma, se atribui um conceito mais amplo de inter ou mesmo transdisciplinaridade, superando a mera relação entre as disciplinas, mas compreendendo a totalidade extensiva do real e a totalidade intensiva da obra.

A tarefa do professor de literatura ou mesmo de quaisquer áreas não é simples. Reduzir o acesso às objetivações humanas que auxiliam no processo de conhecimento e autoconhecimento do ser e do mundo, como a ciência e a arte, é tarefa da sociedade capitalista e do seu aparato de produção e reprodução. Encontrar meios para burlá-lo é dever dos membros da classe trabalhadora, em especial de seus intelectuais orgânicos, nos termos de Antônio Gramsci. O professor consciente para a luta proletária tem, então, a tarefa revolucionária de lutar pelos direitos educacionais dos trabalhadores, como o acesso à arte e à educação. Se inserir esse acesso em seu programa disciplinar pode ser um espaço de contradição, é preciso fazê-lo consciente dos limites e possibilidades reais dessa ação.

\section{REFERÊNCIAS}

ABENDROTH, Wolfgang; HOLZ, Hans Heinz; KOFLER, Leo. Conversando com Lukács. Rio de Janeiro, Ed. Paz e Terra, 1a ed., 1969.

BRASIL. Ministério da Educação. Secretaria de Educação Básica. Linguagens, códigos e suas tecnologias. Brasília: MEC, 2006. 239 p. (Orientações curriculares para o ensino médio; volume 1).

BRASIL. Ministério da Educação. Secretaria de Educação Média e Tecnológica. Parâmetros Curriculares Nacionais (Ensino Médio). Brasília: MEC, 2000.

BRASIL. República Federativa do Brasil. Lei no 9.394: Estabelece as Diretrizes e Bases da Educação Nacional. Brasília, 1996.

BRASIL. República Federativa do Brasil. Parecer CNE/CEB no 15/1998. Diretrizes Curriculares Nacionais para o Ensino Médio. 1998.

LUKÁCS, Georg. Estetica 1 - La peculiaridad de lo estetico. Traducción de Manuel Sacristán. V. 2 Barcelona: Ediciones Grijaldo, 1982.

Marxismo e teoria da literatura. São Paulo: Expressão Popular, 2010. 
Materialiales sobre el realismo. Traducción de Manuel Sacristán. Barcelona:

Ediciones Grijalbo, 1977.

LUKÁCS, György. Arte e sociedade: escritos estéticos 1932-1967. Organização e tradução de Carlos Nelson Coutinho e José Paulo Netto. 2 ed. Rio de Janeiro: Editora UFRJ, 2011.

Ensaios sôbre literatura. Tradução de Leandro Konder. Rio de Janeiro: Editora Civilização Brasileira S.A., 1965. 235 p.

Escritos de Moscú: estudios sobre política y literatura. Buenos Aires: Gorla, 2011. Tradução de Miguel Vedda y Martín Koval.

Introdução a uma Estética Marxista: Sôbre a Particularidade como Categoria da Estética. Tradução de Carlos Nelson Coutinho e Leandro Konder. 2ª ed. Rio de Janeiro: Civilização Brasileira, 1978.

Problemas del realismo. Traducción de Carlos Gerhard. México D.F: Fondo de Cultura Economica, 1966.

SAVIANI, Demerval. O trabalho como princípio educativo frente às novas tecnologias. In: FERRETI, Celso João (Org.). Novas tecnologias, trabalho e educação: um debate multidisciplinar. Petrópolis: Vozes, 1994.

TONET, Ivo. Educação, cidadania e emancipação humana. 2. ed. Maceió: EDUFAL, 2013. 